Correspondence

Kasthuri Venkateswaran kjvenkat@jpl.nasa.gov

\section{Description of Rummeliibacillus stabekisii gen. nov., sp. nov. and reclassification of Bacillus pycnus Nakamura et al. 2002 as Rummeliibacillus pycnus comb. nov.}

Parag Vaishampayan, ${ }^{1}$ Mika Miyashita, ${ }^{2}$ Akihiro Ohnishi, ${ }^{3}$ Masataka Satomi, ${ }^{4}$ Alejandro Rooney, ${ }^{5}$ Myron T. La Duc ${ }^{1}$ and Kasthuri Venkateswaran ${ }^{1}$

\author{
${ }^{1}$ Biotechnology and Planetary Protection Group, Jet Propulsion Laboratory, California Institute of \\ Technology, Pasadena, CA 91109, USA \\ ${ }^{2}$ National Institute of Technology and Evaluation, Biological Resource Center, Kazusakamatari, \\ Kisarazu, Chiba 292-0818, Japan \\ ${ }^{3}$ Department of Fermentation Science, Faculty of Applied Bio-Science, Tokyo University of \\ Agriculture, 1-1 Sakuragaoka 1-chome, Setagaya-ku, Tokyo 156-8502, Japan \\ ${ }^{4}$ National Research Institute of Fisheries Science, Fisheries Research Agency, Yokohama 236- \\ 8648, Japan \\ ${ }^{5}$ National Center for Agricultural Utilization Research, US Department of Agriculture, Peoria, IL \\ 61604, USA
}

\begin{abstract}
Strains of aerobic, Gram-positive, rod-shaped, round-spore-forming bacteria were isolated from different geographical locations and a subsequent polyphasic study was undertaken to clarify the taxonomic position of the round-spore-forming isolates strain $\mathrm{KSC}-\mathrm{SF} 6 \mathrm{~g}^{\top}$, strain $\mathrm{M} 32$ and strain NBRC 12622. 16S rRNA gene sequence similarities demonstrated that these strains were most closely affiliated with Bacillus pycnus NRRL NRS- $1691^{\top}(98 \%)$, with species of Kurthia (96\%) and Viridibacillus (94-96\%) as the next nearest relatives. However, while DNA-DNA hybridization studies showed approx. $70 \%$ reassociation among strains $\mathrm{KSC} \mathrm{SF} 6 \mathrm{~g}^{\top}, \mathrm{M} 32$ and NBRC 12622, DNA-DNA hybridization values between these strains and B. pycnus NRRL NRS- $1691^{\top}$ never exceeded $13 \%$. Differences in the molecular structure of the cell-wall peptidoglycan could not differentiate these strains sufficiently from other closely related genera (Viridibacillus and Kurthia). However, Lys-Asp was present in strains KSC-SF6g ${ }^{\top}, \mathrm{M} 2$ and NBRC 12622, whereas L-Lys-D-Glu was reported in $B$. pycnus NRRL NRS-1691 ${ }^{\top}$. The menaquinone MK-7 was dominant in strains KSC-SF6g ${ }^{\top}, \mathrm{M} 32$ and NBRC 12622 and members of the genus Kurthia, whereas MK-8 was abundant in Viridibacillus species. Strains KSC-SF6g ${ }^{\top}$, M32 and NBRC 12622 exhibited fatty acid profiles consisting of major amounts of anteiso- $\mathrm{C}_{15: 0}(\sim 50 \%)$ and iso- $\mathrm{C}_{15: 0}(\sim 25 \%)$ and moderate amounts of anteiso- $\mathrm{C}_{17: 0}$ $(\sim 7 \%)$, which discriminated them from closely related B. pycnus NRRL NRS-1691 ${ }^{\top}$ and species of Viridibacillus (iso- $\mathrm{C}_{15: 0} ; 46-74 \%$ ). The authors propose that strains $\mathrm{KSC}-\mathrm{SF} 6 \mathrm{~g}^{\top}, \mathrm{M} 32$ and NBRC 12622 and $B$. pycnus NRRL NRS $-1691^{\top}$ be reclassified into a separate genus based on clear-cut differences in discriminative taxonomic markers and the distant placement of $B$. pycnus and the novel strains described herein from other species of this clade according to current 16S rRNA gene sequence-based relatedness ( $4 \%$ difference in sequence). We propose the placement of these isolates into the novel genus Rummeliibacillus gen. nov. For the new taxon comprising strains KSCSF6g ${ }^{\top}$, M32 and NBRC 12622, we propose the name Rummeliibacillus stabekisii gen. nov., sp. nov. (the type species of Rummeliibacillus), represented by the type strain KSC-SF6g ${ }^{\top}$ (=NRRL B-51320 ${ }^{\top}$ $=$ NBRC $104870^{\top}$ ). In addition, Bacillus pycnus, which bears traits distinct from other round-sporeforming species [i.e. absence of growth at high $\mathrm{NaCl}$ (7\%), positive reaction for gelatin liquefaction], is reclassified as Rummeliibacillus pycnus comb. nov. (type strain JCM $11075^{\top}=$ NRRL NRS-1691 ${ }^{\top}$ ) based on phylogenetic affiliations and phenotypic characterization.
\end{abstract}

The GenBank/EMBL/DDBJ accession numbers for the 16S rRNA gene sequences of strains KSC-SF6g ${ }^{\top}$, M32 and NBRC 12622 are DO870754, $A B 116126$ and $A B 271737$, respectively.

A comparison of the fatty acid profiles of the novel strains and related strains is available as a supplementary table with the online version of this paper. 
The round-spore-forming, mesophilic bacterial species Bacillus sphaericus was first described in 1904 (Neide, 1904). Inadequate taxonomic classification tools and the lack of modern-day molecular approaches restricted further phylogenetic subdivision of this heterogeneous species. The introduction of DNA-based comparative methodologies has recently triggered the reclassification of the species B. sphaericus, leading to the discovery of novel mesophilic species such as Bacillus fusiformis (Priest et al., 1988), Bacillus silvestris (Rheims et al., 1999) and Bacillus odysseyi (La Duc et al., 2004). Likewise, B. sphaericus-like species were segregated into seven groups (Nakamura, 2000) based on a molecular approach, and groups 6 and 7 were further characterized as Bacillus pycnus and Bacillus neidei, respectively (Nakamura et al., 2002). As members of this B. sphaericus-like group shared 95.196.6 \% 16S rRNA gene sequence similarity with non-sporeforming species of Kurthia, Ash et al. (1991) deemed Kurthia species to be members of Bacillus rRNA group 2. The species Bacillus arvi, Bacillus arenosi and B. neidei exhibited high $16 \mathrm{~S}$ rRNA gene sequence similarity (97.1$99.8 \%$ ) with one another, whereas B. pycnus appeared to be distantly related to these three species (95.2-96.7\%). Recently, B. neidei was reclassified along with $B$. arvi and $B$. arenosi into the novel genus Viridibacillus (Albert et al., 2007). The same study suggested that B. pycnus be examined and considered as a representative of a possible novel genus.

To understand better the physiological breadth enveloped within the microbial populations encountered while surveying spacecraft-associated microbial diversity, polyphasic taxonomic studies are routinely undertaken to clarify the taxonomic positions of isolates. Several novel physiologically recalcitrant, phylogenetically distinct micro-organisms have been encountered while examining spacecraft surfaces (La Duc et al., 2007; Osman et al., 2006; Satomi et al., 2006). Some of these micro-organisms form round spores surrounded by an exosporium (La Duc et al., 2004; Venkateswaran et al., 2003), which probably renders such entities much more tolerant of various clean-room conditions and enhances the adhesion of spores to spacecraft surfaces. A novel spore-forming bacterial species comprising three strains was isolated from various geographical locations: the floor of a class $100 \mathrm{~K}$ spacecraft-assembly clean room at the Kennedy Space Center, Florida, USA (strain KSC-SF6g ${ }^{\mathrm{T}}$; La Duc et al., 2007), a field-scale composter in Japan (strain M32) and an unknown source (strain NBRC 12622, deposited in the culture collection of the Institute of Fermentation, Osaka, Japan). This novel species, along with previously described strains of $B$. pycnus, are here reclassified into a novel genus based on polyphasic taxonomic analyses. The type strain of B. pycnus, NRRL NRS- $1691^{\mathrm{T}}$, was included for comparative analyses.

Strains KSC-SF6g ${ }^{\mathrm{T}}$, M32 and NBRC 12622 showed growth on tryptic soy agar (TSA; Difco) after $24 \mathrm{~h}$ at $32{ }^{\circ} \mathrm{C}$. Colonies were regular-edged, non-pigmented, translucent, smooth and circular, with a mean diameter of about $1 \mathrm{~mm}$ after $24 \mathrm{~h}$ of incubation on TSA at $32{ }^{\circ} \mathrm{C}$. Upon extended incubation, colonies did not yield any pigmentation. A modified Schaeffer's medium (MSM) was used to induce sporulation (Kempf et al., 2005). MSM consists of $0.1 \%$ $\mathrm{KCl}, 0.012 \% \mathrm{MgCl}_{2}, 1.0 \mathrm{mM} \mathrm{Ca}\left(\mathrm{NO}_{3}\right)_{2}, 0.01 \mathrm{mM} \mathrm{MnCl}$, $0.001 \mathrm{mM} \mathrm{FeSO}_{4}$ and $8 \mathrm{~g}$ nutrient broth in 1.01 distilled deionized water. A single purified colony of strains KSCSF6g ${ }^{T}$, M32 and NBRC 12622 was inoculated individually in MSM broth. After $24 \mathrm{~h}$ of incubation at $32{ }^{\circ} \mathrm{C}$, cultures were examined by wet-mount light microscopy to determine the level of sporulation. Once the number of free spores was greater than $99 \%$, they were harvested by centrifugation and purified by treatment with lysozyme and washing with salts and detergents (Nicholson \& Setlow, 1990). Purified spores were resuspended in sterile deionized water, heat-treated $\left(80{ }^{\circ} \mathrm{C}\right.$ for $\left.15 \mathrm{~min}\right)$ to ensure inactivation of the vegetative population and stored at $4{ }^{\circ} \mathrm{C}$ in glass tubes.

The morphologies of vegetative cells $(24 \mathrm{~h}$ incubation at $32{ }^{\circ} \mathrm{C}$ on TSA) and purified spores were observed by phasecontrast microscopy using an Olympus microscope (BX60). Scanning electron microscopy (NOVA nanoSEM600; EDAX) (Cole \& Popkin, 1981) and transmission electron microscopy (FEI Inc.) were performed to examine surface details and spore architecture. Samples were prepared for transmission electron microscopy as follows. Sporulating cells $\left(500 \mu \mathrm{l} ; 10^{7}\right.$ cells) were gently concentrated at 3000 r.p.m. and fixed in $0.1 \mathrm{M}$ sodium cacodylate buffer containing $2.5 \%$ glutaraldehyde $(\mathrm{pH} 7.2)$ at $4{ }^{\circ} \mathrm{C}$ for $24 \mathrm{~h}$. The suspension was mixed with $2 \%$ agarose to bind sporulating cells, which were then fixed in $0.1 \mathrm{M}$ sodium cacodylate buffer containing $2 \%$ osmium tetroxide ( $\mathrm{pH}$ 7.2) for $2 \mathrm{~h}$. The cell suspension was further washed with increasing concentrations of alcohol and finally embedded in epoxy resin. Thin sections of these preparations $(50 \mathrm{~nm}$ ) were made using an ultramicrotome (Leica Microsystems) and subsequently stained with aqueous $2 \%$ uranyl acetate and Reynolds' lead citrate to enhance contrast.

All strains yielded positive Gram reactions, according to established Gram-stain procedures (Smibert \& Krieg, 1994). Fig. 1(a) depicts endospore-forming cells terminally swollen with phase-bright spore bodies, as viewed under a phase-contrast light microscope. The spherical nature $(\sim 1 \mu \mathrm{m}$ in diameter) of the spore bodies was apparent when viewed with a scanning electron microscope, as shown in Fig. 1(b). Transmission electron micrographs (Fig. 1c, d) showed the presence of an exosporium, a unique layer that is an integral part of certain Bacillus spores, such as those of B. odysseyi (La Duc et al., 2004).

Bacterial 16S rRNA genes were amplified by PCR using the eubacteria-biased B27f and universal 1492r primer set, as described previously (Satomi et al., 2006). The phylogenetic relationships of isolates included in this study were determined by comparison of individual 16S rRNA gene 


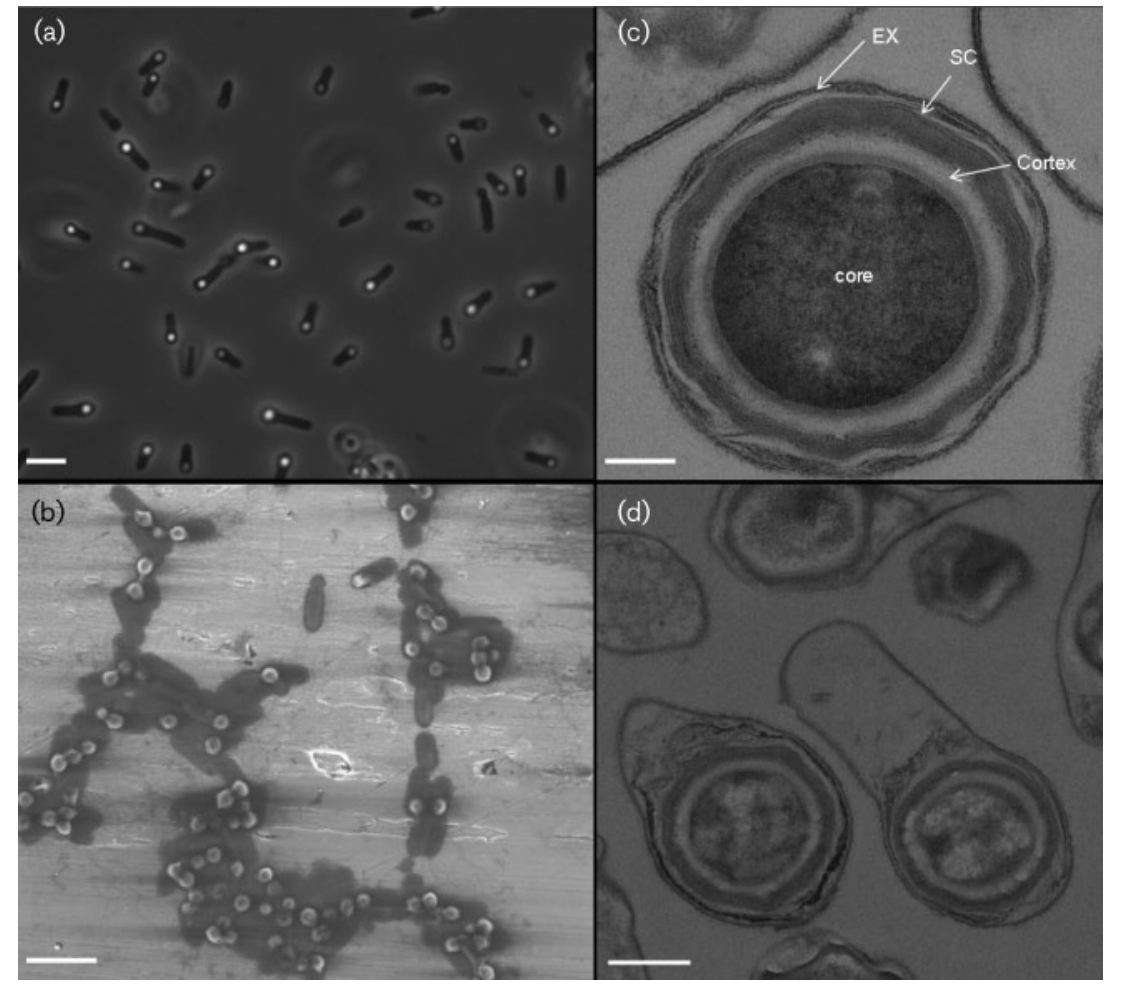

Fig. 1. (a, b) Microscope images of Rummeliibacillus stabekisii gen. nov., sp. nov. $\mathrm{KSC}-\mathrm{SF} 6 \mathrm{~g}^{\top}$ showing sporulating (bright structures) and vegetative cells using light microscopy (a) and round-spore structures using scanning electron microscopy (b). (c, d) Transmission electron micrographs of spore architecture of strain $\mathrm{KSC}-\mathrm{SF} 6 \mathrm{~g}^{\top}$ with cross section of a single spore (c) and a mother cell engulfing a spore (d). EX, Exosporium; SC, spore coat. Bars, $2.5 \mu \mathrm{m}$ (a), $4 \mu \mathrm{m}$ (b), $0.2 \mu \mathrm{m}$ (c) and $0.5 \mu \mathrm{m}$ (d). sequences to existing sequences in public databases (http:// www.ncbi.nlm.nih.gov/). The similarities observed in $16 \mathrm{~S}$ rRNA gene sequences demonstrated that strain KSC-SF6 ${ }^{\mathrm{T}}$ is phylogenetically affiliated most closely with strains M32 and NBRC 12622 (99.86\%) and B. pycnus NRRL NRS$1691^{\mathrm{T}}(97.96 \%)$. According to $16 \mathrm{~S}$ rRNA gene sequence similarity, members of Viridibacillus (maximum similarity of $95.85 \%$ ) and several species of Kurthia (95.35-96.29\%) were the next nearest relatives to the novel strains. Bacillus subtilis IAM $12118^{\mathrm{T}}$ exhibited very low sequence similarity $(90.17 \%)$. When neighbour-joining phylogenetic analyses were performed with the program MEGA4 (Tamura et al., 2007), strains KSC-SF6g ${ }^{\mathrm{T}}, \mathrm{M} 32$ and NBRC 12622 formed a distinct cluster with B. pycnus NRRL NRS- $1691^{\mathrm{T}}$ (Fig. 2). It is clear from the resulting phylogenetic tree that these strains are distant relatives of members of the genera Kurthia, Viridibacillus, Caryophanon and Lysinibacillus (Fig. 2).

The ability to grow in varying concentrations of $\mathrm{NaCl}$ (1$10 \%, \mathrm{w} / \mathrm{v}$ ) was determined in $1 \%$ Bacto tryptone containing varying amounts of $\mathrm{NaCl}$. Isolates were also grown in $1 \%$ tryptone to examine their ability to grow in the absence of $\mathrm{NaCl}$ (Satomi et al., 2006). The novel strains described herein were halotolerant and capable of growth in the presence of up to $7 \% \mathrm{NaCl}$, in contrast to B. pycnus

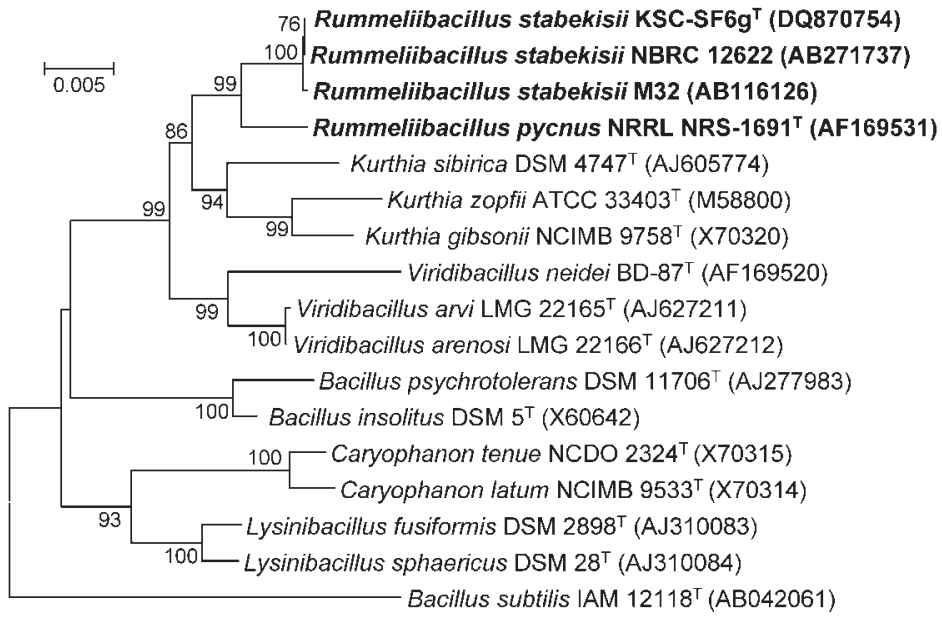

Fig. 2. Phylogenetic analysis based on $16 \mathrm{~S}$ rRNA gene sequences using a neighbourjoining algorithm showing the position of strains of Rummeliibacillus stabekisii gen. nov., sp. nov. with their closest relatives. Bar, 0.005 substitutions per nucleotide position. Bootstrap values at nodes are percentages based on estimation of 1000 trees by the neighbour-joining method. 
NRRL NRS- $1691^{\mathrm{T}}$, which did not exhibit any growth at $7 \% \mathrm{NaCl}$. Commercially available API $20 \mathrm{NE}$ and API 50 $\mathrm{CH}$ test strips (bioMérieux) were used, according to the manufacturer's specifications, to characterize each of the strains biochemically. Table 1 summarizes the physiological and biochemical traits of each of the strains examined in this study. Notable discriminative factors not shared between the novel strains and B. pycnus include the novel strains' ability to liquefy gelatin, their inability to break down tryptophan to indole and their inability to produce acid from glucose (Table 1).

Cellular fatty acid methyl esters were analysed with the Microbial ID system (MIDI, Inc.) according to the manufacturer's instructions and the results are provided in Supplementary Table S1 (available in IJSEM Online). No significant differences were observed when the cellular fatty acid profiles of strains KSC-SF6g ${ }^{\mathrm{T}}$, M32 and NBRC 12622 were compared with one another, supporting their affiliation to a single species. The profile of $B$. pycnus NRRL NRS- $1691^{\mathrm{T}}$ differed from the profiles of strains KSC-SF6g ${ }^{\mathrm{T}}, \mathrm{M} 32$ and NBRC 12622 in the content of iso$\mathrm{C}_{15: 0}, \mathrm{C}_{14: 0}$ and anteiso- $\mathrm{C}_{15: 0}$ and the lack of $\mathrm{C}_{12: 0}, \mathrm{C}_{15: 0}$ and $\mathrm{C}_{16: 0}$. When the fatty acid methyl ester profiles of members of the genus Viridibacillus (Albert et al., 2007) were compared with those of B. pycnus NRRL NRS- $1691^{\mathrm{T}}$ and the novel strains (Supplementary Table S1), significant differences were observed in the content of iso- $\mathrm{C}_{14: 0}$, iso$\mathrm{C}_{15: 0}$, iso- $\mathrm{C}_{17: 1} \omega 10 c$, iso- $\mathrm{C}_{17: 0}$ and iso- $\mathrm{C}_{17: 1} \mathrm{I} /$ anteiso$\mathrm{C}_{17: 1} \mathrm{~B}$ and the lack of $\mathrm{C}_{15: 0}$. The fatty acid profile comparison clearly segregates isolates KSC-SF6g ${ }^{\mathrm{T}}$, M32 and NBRC 12622 from B. pycnus NRRL NRS-1691 ${ }^{\mathrm{T}}$ and species of Viridibacillus, which, coupled with its deep-branching molecular phylogeny, advocates novel genus status for this group. Characteristics used to differentiate the novel genus described herein from related genera are shown in Table 2.

Respiratory quinones were extracted according to the method of Nakagawa \& Yamasato (1993) and determined by using LC-MS ( $8000 \alpha$; Shimadzu). The quinone system of B. pycnus NRRL NRS- $1691^{\mathrm{T}}$ was dominated (>99\%) by the menaquinone MK-7, with trace amounts of MK-8 (Table 2). However, for Viridibacillus arvi DSM $16317^{\mathrm{T}}, V$. arenosi DSM $16319^{\mathrm{T}}$ and $V$. neidei NRRL BD- $87^{\mathrm{T}}$, the primary isoprenoid quinone was MK-8 (69-81\%), with MK-7 present at $19-30 \%$ and MK-6 present in trace amounts (Albert et al., 2007). Cell walls were prepared by mechanical disruption with an ultrasonic oscillator and were purified as described elsewhere (Schleifer \& Kandler, 1972). The amino acid compositions of complete cell-wall hydrolysates were determined by HPLC with a model LC20A (Shimadzu). The novel strains contained peptidoglycan with alanine, glutamic acid, lysine and aspartic acid, indicating that the peptidoglycan type is A4 $\alpha$ (Lys-Asp) according to Schleifer \& Kandler (1972), while B. pycnus NRRL NRS- $1691^{\mathrm{T}}$ was reported to contain L-Lys-D-Glu (Nakamura et al., 2002).

DNA was extracted from all strains according to established protocols (Johnson, 1981). The genomic DNA of strain NBRC 12622 was found to have a G+C content of $37.3 \mathrm{~mol} \%$, as determined by adhering to previously published protocols (Saha et al., 2005). DNA-DNA hybridization was performed using previously reported microplate hybridization methods (Ezaki et al., 1989). Isolates KSC$\mathrm{SF}^{\mathrm{T}} \mathrm{g}^{\mathrm{T}}, \mathrm{M} 32$ and NBRC 12622 were closely related to each other (approx. $70 \%$ DNA relatedness), indicating that these novel strains were indeed members of the same species. These strains exhibited relatively low levels of reassociation with $B$. pycnus NRRL NRS- $1691^{\mathrm{T}}$ (13\%) and strains of Kurthia (15$17 \%)$. Nakamura et al. (2002) have previously reported high levels (100\%) of DNA relatedness between B. pycnus NRRL NRS- $1691^{\mathrm{T}}$ and other strains (NRRL NRS-1694, NRRL NRS1693 and NRRL NRS-1695). Thus, according to the results of DNA-DNA hybridizations, strains KSC-SF6 $\mathrm{g}^{\mathrm{T}}, \mathrm{M} 32$ and NBRC 12622 are members of a species which is distinct from B. pycnus NRRL NRS- $1691^{\mathrm{T}}$.

Phylogenetic analyses based on the 16S rRNA gene sequences of strains KSC-SF6g ${ }^{\mathrm{T}}$, M32 and NBRC 12622

Table 1. Differentiating characteristics between the novel strains and $B$. pycnus NRRL NRS-1691 ${ }^{\top}$

Strains: 1, B. pycnus NRRL NRS-1691 ${ }^{\mathrm{T}}$; 2 , KSC-SF6g ${ }^{\mathrm{T}}$; 3, NBRC 12622; 4, M32. All data were obtained in this study. All strains are motile and positive for growth in $5 \% \mathrm{NaCl}$ and negative for oxidase, growth in $10 \% \mathrm{NaCl}$, starch hydrolysis, citrate utilization and acid production from D-arabinose, D-ribose, D-xylose, D-galactose, D-glucose, Dlactose, D-mannose, D-mannitol and cellobiose.

\begin{tabular}{|c|c|c|c|c|}
\hline Characteristic & 1 & 2 & 3 & 4 \\
\hline Temperature range $\left({ }^{\circ} \mathrm{C}\right)$ & $10-45$ & $28-55$ & $15-45$ & $28-55$ \\
\hline Growth in $7 \% \mathrm{NaCl}$ & - & + & + & + \\
\hline Gelatin hydrolysis & - & + & + & + \\
\hline Cell-wall type & L-Lys-D-Glu & Lys-Asp & Lys-Asp & Lys-Asp \\
\hline Indole production & + & - & - & - \\
\hline $\begin{array}{l}\text { Acid production from D- } \\
\text { glucose }\end{array}$ & + & - & - & - \\
\hline Major fatty acid & iso- $\mathrm{C}_{15: 0}$ & anteiso- $\mathrm{C}_{15: 0}$ & anteiso- $\mathrm{C}_{15: 0}$ & anteiso- $\mathrm{C}_{15: 0}$ \\
\hline
\end{tabular}


Table 2. Characteristics that distinguish members of the genus Rummeliibacillus gen. nov. from related genera and $B$. subtilis

Data for reference taxa were taken from Nakamura et al. (2002) (B. pycnus), Albert et al. (2007) (Viridibacillus), Shaw \& Keddie (1983) (Kurthia), Ahmed et al. (2007) (Lysinibacillus) and Kämpfer (1994) (B. subtilis). Dap, Diaminopimelic acid.

\begin{tabular}{|c|c|c|c|c|c|}
\hline Characteristic & Rummelibacillus & Viridibacillus & Kurthia & Lysinibacillus & B. subtilis \\
\hline Spore formation & Present & Present & Absent & Present & Present \\
\hline Cell-wall composition & $\begin{array}{c}\text { L-Lys-D-Glu or } \\
\text { Lys-Asp }\end{array}$ & $\begin{array}{l}\text { L-Lys-D-Glu or } \\
\text { L-Lys-D-Asp }\end{array}$ & L-Lys-D-Asp & Lys-Asp & meso-Dap direct \\
\hline Green pigment formation & Absent & Present & Absent & Absent & Absent \\
\hline Quinone system & MK-7 & MK-8, MK-7 & MK-7 & MK-7 & MK-7 \\
\hline Polar lipids ${ }^{*}$ & $\begin{array}{c}\text { DPG, PE, PG, APL, } \\
\text { 2PL, AL }\end{array}$ & $\begin{array}{l}\text { DPG, PE, PG, } \\
\text { APL, 2PL }\end{array}$ & DPG, PE, PG & DPG, PG, APGL & $\begin{array}{l}\text { PG, DPG, PE, } \\
\text { GBG, APL }\end{array}$ \\
\hline Major fatty acids $(>10 \%) \dagger$ & $\begin{array}{l}\text { iso- } \mathrm{C}_{15: 0} \\
\text { anteiso- } \mathrm{C}_{15: 0}\end{array}$ & $\begin{array}{l}\text { iso- } \mathrm{C}_{15: 0}, \\
\left(\text { anteiso- } \mathrm{C}_{15: 0}\right)\end{array}$ & $\begin{array}{l}\text { iso- } \mathrm{C}_{15: 0} \\
\text { anteiso- } \mathrm{C}_{15: 0}\end{array}$ & $\begin{array}{c}\text { iso- } \mathrm{C}_{15: 0}, \text { (anteiso- } \\
\mathrm{C}_{15: 0} \text {, iso- } \mathrm{C}_{16: 0} \\
\text { anteiso- } \mathrm{C}_{17: 0} \\
\mathrm{C}_{16: 1} \omega 7 \mathrm{c} \text { alcohol) }\end{array}$ & $\begin{array}{l}\text { anteiso- } \mathrm{C}_{15: 0}, \\
\text { iso- } \mathrm{C}_{15: 0} \\
\text { anteiso- } \mathrm{C}_{17: 1}\end{array}$ \\
\hline
\end{tabular}

*AL, Unknown aminolipid; APGL, unknown aminophosphoglycolipid; APL, unknown aminophospholipid; DPG, diphosphatidylglycerol; GBG, gentiobiosyldiacylglycerol; PE, phosphatidylethanolamine; PG, phosphatidylglycerol; PL, unknown phospholipid.

$\dagger$ Fatty acids given in parentheses are present at $>10 \%$ in some members of the genus.

and B. pycnus NRRL NRS- $1691^{\mathrm{T}}$ portray this assemblage as a distinct sublineage, having sequence divergence of $>4 \%$ from members of the closely related genera Kurthia and Viridibacillus. This discriminatory phylogenetic inference was supported by phenotypic differences (Table 1) and DNA-DNA hybridization. On the basis of distinguishing chemotaxonomic and genotypic attributes, we propose the classification of strains KSC-SF6g ${ }^{\mathrm{T}}$, M32 and NBRC 12622 and all previously described B. pycnus strains into a novel genus designated Rummelibacillus gen. nov. The name Rummeliibacillus stabekisii sp. nov. is proposed for strains $\mathrm{KSC}^{-S F 6 g}{ }^{\mathrm{T}}, \mathrm{M} 32$ and NBRC 12622. We further propose the reclassification of Bacillus pycnus as Rummeliibacillus pycnus comb. nov.

\section{Description of Rummeliibacillus gen. nov.}

Rummeliibacillus (Rum.me'li.i.ba.cil'lus. N.L. n. Rummelius Rummel; L. masc. n. bacillus a rod, and also a bacterial genus name; N.L. masc. n. Rummeliibacillus a bacterium close to the genus Bacillus and named in honour of former NASA Planetary Protection Officer Dr John Rummel, an astrobiologist responsible for bringing planetary protection into the public domain).

Gram-positive, spore-forming, motile rods. Endospores are round and are located terminally with an exosporium. Growth occurs at $28-55{ }^{\circ} \mathrm{C}$ and in the presence of up to $5 \% \mathrm{NaCl}(\mathrm{w} / \mathrm{v})$. Sporulation is observed in MSM broth after $72 \mathrm{~h}$ at $32{ }^{\circ} \mathrm{C}$. The quinone system consists of MK-7 as the most prevalent compound. The polar lipid profile consists of the major compounds diphosphatidylglycerol, phosphatidylglycerol and phosphatidylethanolamine, moderate amounts of an unknown aminophospholipid (APL1), minor amounts of two unknown phospholipids (PL1, PL2) and an unknown aminolipid (AL). Fatty acid profiles consist largely of anteiso- $\mathrm{C}_{15: 0}$ (approx. 50\%) and iso$\mathrm{C}_{15: 0}$ (approx. $25 \%$ ) acids along with moderate amounts of anteiso- $\mathrm{C}_{17: 0}$ (approx. $7 \%$ ). Cell-wall peptidoglycan is L-Lys-D-Glu or Lys-Asp. The $\mathrm{G}+\mathrm{C}$ content of the genomic DNA of the type strain of the type species of the genus is $34.3 \mathrm{~mol} \%$. The type species is Rummeliibacillus stabekisii.

\section{Description of Rummeliibacillus stabekisii sp. nov.}

Rummeliibacillus stabekisii (sta.be.ki'si.i. N.L. gen. masc. n. stabekisii of Stabekis, in honour of Perry Stabekis, a great source of advice and wisdom to the NASA Planetary Protection Program and its officers).

Displays the following characteristics in addition to those given in the genus description. Rods are 1.07-1.14 × 2.64$3.32 \mu \mathrm{m}$ (from scanning electron micrographs). Agar colonies are non-pigmented, translucent, smooth, circular and entire with a mean diameter of about $1 \mathrm{~mm}$ after $24 \mathrm{~h}$ of incubation at $32{ }^{\circ} \mathrm{C}$ on TSA. Optimum growth temperature is $28-32{ }^{\circ} \mathrm{C}$ (no growth at $5-10$ or $65{ }^{\circ} \mathrm{C}$ ). Strictly aerobic, oxidase-negative, does not reduce nitrate to nitrite, liquefies gelatin, grows in up to $7 \% \mathrm{NaCl}$, hydrolyses starch, utilizes citrate and produces acid from D-arabinose, D-ribose, D-xylose, D-galactose, D-glucose, Dlactose, D-mannose, D-mannitol and cellobiose. Cell-wall peptidoglycan is of type Lys-Asp.

The type strain, KSC-SF6g ${ }^{\mathrm{T}}$ (=NRRL B-51320 ${ }^{\mathrm{T}}=\mathrm{NBRC}$ $104870^{\mathrm{T}}$ ), was isolated from the Payload Hazardous Servicing Facility at the Kennedy Space Center, FL, USA. Strains M32 and NBRC 12622 are additional strains of the species. 


\section{Description of Rummeliibacillus pycnus (Nakamura et al. 2002) comb. nov.}

Rummeliibacillus pycnus (pyc'nus. N.L. masc. adj. pycnus from Gr. adj. puknos thick, referring to the thick cells).

Basonym: Bacillus pycnus Nakamura et al. 2002.

In addition to the characteristics of $B$. pycnus summarized by Nakamura et al. (2002), the species exhibits the traits listed in the genus description above. The type strain is NRRL NRS-1691 ${ }^{\mathrm{T}}\left(=\mathrm{JCM} 11075^{\mathrm{T}}\right)$.

\section{Acknowledgements}

The research described in this publication was carried out at the Jet Propulsion Laboratory, California Institute of Technology, under a contract with the National Aeronautics and Space Administration. This research was funded by a 2006 NRA-ROSES grant. We are grateful to Cassie Conley for such funding. The authors extend thanks to Shariff Osman for sampling and to all of the members of the JPL Biotechnology and Planetary Protection Group for technical assistance.

\section{References}

Ahmed, I., Yokota, A., Yamazoe, A. \& Fujiwara, T. (2007). Proposal of Lysinibacillus boronitolerans gen. nov. sp. nov., and transfer of Bacillus fusiformis to Lysinibacillus fusiformis comb. nov. and Bacillus sphaericus to Lysinibacillus sphaericus comb. nov. Int J Syst Evol Microbiol 57, 1117-1125.

Albert, R. A., Archambault, J., Lempa, M., Hurst, B., Richardson, C., Gruenloh, S., Duran, M., Worliczek, H. L., Huber, B. E. \& other authors (2007). Proposal of Viridibacillus gen. nov. and reclassification of Bacillus arvi, Bacillus arenosi and Bacillus neidei as Viridibacillus arvi gen. nov., comb. nov., Viridibacillus arenosi comb. nov. and Viridibacillus neidei comb. nov. Int J Syst Evol Microbiol 57, 2729-2737.

Ash, C., Farrow, J. A. E., Wallbanks, S. \& Collins, M. D. (1991). Phylogenetic heterogeneity of the genus Bacillus revealed by comparative analysis of small subunit-ribosomal RNA sequences. Lett Appl Microbiol 13, 202-206.

Cole, R. M. \& Popkin, T. J. (1981). Electron microscopy. In Manual of Methods for General Bacteriology, pp. 34-51. Edited by P. Gerhardt, R. G. E. Murray, R. N. Costilow, E. W. Nester, W. A. Wood, N. R. Krieg \& G. B. Phillips. Washington, DC: American Society for Microbiology.

Ezaki, T., Hashimoto, Y. \& Yabuuchi, E. (1989). Fluorometric deoxyribonucleic acid-deoxyribonucleic acid hybridization in microdilution wells as an alternative to membrane filter hybridization in which radioisotopes are used to determined genetic relatedness among bacterial strains. Int J Syst Bacteriol 39, 224-229.

Johnson, J. L. (1981). Genetic characterization. In Manual of Methods for General Bacteriology, pp. 450-472. Edited by P. Gerhardt, R. G. E. Murray, R. N. Costilow, E. W. Nester, W. A. Wood, N. R. Krieg \& G. B. Phillips. Washington, DC: American Society for Microbiology.

Kämpfer, P. (1994). Limits and possibilities of total fatty acid analysis for classification and identification of Bacillus species. Syst Appl Microbiol 17, 86-98.
Kempf, M. J., Chen, F., Kern, R. \& Venkateswaran, K. (2005). Recurrent isolation of hydrogen peroxide-resistant spores of Bacillus pumilus from a spacecraft assembly facility. Astrobiology 5, 391-405.

La Duc, M. T., Satomi, M. \& Venkateswaran, K. (2004). Bacillus odysseyi sp. nov., a round-spore-forming bacillus isolated from the Mars Odyssey spacecraft. Int J Syst Evol Microbiol 54, 195-201.

La Duc, M. T., Dekas, A. E., Osman, S., Moissl, C., Newcombe, D. \& Venkateswaran, K. (2007). Isolation and characterization of bacteria capable of tolerating the extreme conditions of clean-room environments. Appl Environ Microbiol 73, 2600-2611.

Nakagawa, Y. \& Yamasato, K. (1993). Phylogenetic diversity of the genus Cytophaga revealed by $16 \mathrm{~S}$ rRNA sequencing and menaquinone analysis. J Gen Microbiol 139, 1155-1161.

Nakamura, L. K. (2000). Phylogeny of Bacillus sphaericus-like organisms. Int J Syst Evol Microbiol 50, 1715-1722.

Nakamura, L. K., Shida, O., Takagi, H. \& Komagata, K. (2002). Bacillus pycnus sp. nov. and Bacillus neidei sp. nov., round-spored bacteria from soil. Int J Syst Evol Microbiol 52, 501-505.

Neide, E. (1904). Botanische Beschreibung einiger sporenbildenden Bakterien. Zentralbl Bakteriol Parasitenkd Infektionskr Hyg 12, 337352 (in German).

Nicholson, W. L. \& Setlow, P. (1990). Sporulation, germination and outgrowth. In Molecular Biological Methods for Bacillus, pp. 391-450. Edited by C. R. Harwood \& S. M. Cutting. Chichester: Wiley.

Osman, S., Satomi, M. \& Venkateswaran, K. (2006). Paenibacillus pasadenensis sp. nov. and Paenibacillus barengoltzii sp. nov., isolated from a spacecraft assembly facility. Int J Syst Evol Microbiol 56, 15091514.

Priest, F. G., Goodfellow, M. \& Todd, C. (1988). A numerical classification of the genus Bacillus. J Gen Microbiol 134, 1847-1882.

Rheims, H., Frühling, A., Schumann, P., Rohde, M. \& Stackebrandt, E. (1999). Bacillus silvestris sp. nov., a new member of the genus Bacillus that contains lysine in its cell wall. Int J Syst Bacteriol 49, 795-802.

Saha, P., Krishnamurthi, S., Mayilraj, S., Prasad, G. S., Bora, T. C. \& Chakrabarti, T. (2005). Aquimonas voraii gen. nov., sp. nov., a novel gammaproteobacterium isolated from a warm spring of Assam, India. Int J Syst Evol Microbiol 55, 1491-1495.

Satomi, M., La Duc, M. T. \& Venkateswaran, K. (2006). Bacillus safensis sp. nov., isolated from spacecraft and assembly-facility surfaces. Int J Syst Evol Microbiol 56, 1735-1740.

Schleifer, K. H. \& Kandler, O. (1972). Peptidoglycan types of bacterial cell walls and their taxonomic implications. Bacteriol Rev 36, 407-477.

Shaw, S. \& Keddie, R. M. (1983). A numerical taxonomic study of the genus Kurthia with a revised description of Kurthia zopfii and a description of Kurthia gibsonii sp. nov. Syst Appl Microbiol 4, 253-276.

Smibert, R. M. \& Krieg, N. R. (1994). Phenotypic characterization. In Methods for General and Molecular Bacteriology, pp. 607-654. Edited by P. Gerhardt, R. G. E. Murray, W. A. Wood \& N. R. Krieg. Washington, DC: American Society for Microbiology.

Tamura, K., Dudley, J., Nei, M. \& Kumar, S. (2007). MEGA4: molecular evolutionary genetics analysis (MEGA) software version 4.0. Mol Biol Evol 24, 1596-1599.

Venkateswaran, K., Kempf, M., Chen, F., Satomi, M., Nicholson, W. \& Kern, R. (2003). Bacillus nealsonii sp. nov., isolated from a spacecraftassembly facility, whose spores are gamma-radiation resistant. Int $J$ Syst Evol Microbiol 53, 165-172. 